\title{
A „GERUNDIUM” EGYETEMTÖTÉNEI KÖZLEMÉNYEK ELSŐ ÉVTIZEDÉRŐL
}

(DECENNIUM GERUNDII)

A Debreceni Egyetemen 2009 végén született meg az a döntés, amely - az intézmény közelgő centenáriumára készülve - egyetemtörténeti folyóiratot hozott létre azzal a céllal, hogy állandó készenléttel helyet adjon mind a hazai, mind pedig a nemzetközi felsőoktatás történetére vonatkozó kutatásoknak, forrásközléseknek $\mathrm{s}$ rendszeresen figyelemmel kísérje a témakör szakirodalmát. Miként az alapító főszerkesztő, az akkori rektor Fésüs László a 2010. évi első számban megfogalmazta: az új folyóirat a legmagasabb tudományos igénnyel kívánja szolgálni a hazai és a nemzetközi kutatást, angol nyelvű összefoglalói és világhálós megjelenése révén pedig bárhonnan történő elérést kíván biztosítani a kutatók számára. Noha a folyóirat címében szereplő „gerundium” a debreceni kollégiumi diákság jelképének számít egy fél évszázad óta, a szerkesztőség korántsem helytörténeti orgánumnak, hanem országos és nemzetközi érdekeltségű periodikának szánta a folyóiratot.

Hiánypótló vállalkozásnak bizonyult ez az alapítás, mivel Magyarországon ekkor kifejezetten a hazai és európai felsőoktatás történetével foglalkozó önálló tudományos periodika nem működött, bár különböző fórumokon, konferenciák kiadványaiban és adattári sorozatok tévén növekvő számban jelentek meg az ilyen tárgyú kutatások eredményei. Ezzel szemben külföldön több folyóirat (pl. History of Universities, Oxford; Cambridge Journal of Education; Jahrbuch für Universitätsgeschichte, Münster; Annali di Storia delle Universitá Italiane, Bologna) is ilyen profillal már évtizedek óta folyamatosan dolgozta fel az európai egyetemi mozgalom történetét, fontos oktatásés tudománytörténeti összefüggésekre irányítva a figyelmet. Ezekben a rangos nemzetközi szaklapokban azonban a Kárpát-medence felsőoktatásának története, európai kapcsolatainak adatokban gazdag múltja alig vagy csak nagyon kevéssé kapott helyet. Már csak ezért is indokoltnak mutatkozott tehát egy olyan fórumnak a megteremtése, amely teret ad egyrészt a témakör magyar nézőpontú lokális és regionális kutatásainak, ugyanakkor igyekszik bekapcsolni a magyarországi eredményeket a nemzetközi tudományos élet vérkeringésébe és egyben az európai univerzitások történetét is árnyalja és gazdagítja. Külön öröm, hogy 2014 óta a Pécsi Tudományegyetem holdudvarába tarozó kollégák is felkarolták ezt az ügyet, és színvonalas folyóiratuk (Per aspera ad astra) által mintegy megkettőződtek közös erőfeszítéseink. 
Most - a folyóirat egy évtizedes fennállása alkalmából - érthető módon adódik a kérdés: mennyire sikerült a vállalt feladatokat, a kitűzött célokat teljesíteni, mennyiben lendítette előre a Gerundium a hazai kutatásokat, s vajon sikerült-e ezek révén bekapcsolódni a tágabb európai kontextusba?

Mindenek előtt érdemes utalni a folyóirat közleményeinek müfaji sokszínűségére: tanulmányok, forrásközlések, visszatekintések, adattárak és könyvismertetések egyaránt helyet kaptak benne már a legelső számtól kezdve s ez a törekvés tudatosan végig is kísérte az elmúlt évtized szerkesztőségi munkáját. Eleinte évente csupán egy, majd két szám látott napvilágot, 2015-től kezdve viszont már évi négy számot tudtak megtölteni a beérkezett kéziratok. Örvendetes módon bővült a szerzők köre, egyre inkább országosan elismert fórummá vált a lap, nem utolsó sorban a Szögi László által vezetett budapesti egyetemtörténészekkel, az ELTE körül kialakult kutatócsoporttal történő együttműködés gazdagította profilját. Az 1538-tól datálható debreceni kollégiumi oktatástörténet érthető módon szerepelt a témák között, emellé a centenáriumát ünneplő egyetem múltjának kutatása járult, a modern univerzitás egyes intézeteinek, nemzetközi rangú kutatásainak és rektorainak bemutatása folyamatosan szerepelt a témák között.. Nagy figyelmet fordított a szerkesztőség a határainkon túli intézmények (többek között Kolozsvár, Pozsony, Eperjes) történetére is, a külföldi egyetemek (Róma, Zágráb, Krakkó) hungarológiai képzéseinek áttekintése pedig külön sorozattá bővült $s$ folytatása napirenden van. Szerzőink között az akadémikusoktól kezdve a doktori ösztöndíjasokig minden kutatói korosztály szerepelt, a közlés kritériumaként egyedül a szakmai megbízhatóságot tartottuk szem előtt.

Nyitott volt a Gerundium egész konferenciák anyagának közlésére is, ilyen volt a Reformáció és peregrináció címmel Budapesten rendezett országos tanácskozás előadásainak közlése, ennek a tematikus - és a REFO 500 programjához csatlakozó - számnak kedvező visszhangját jelzik a róla szóló recenziók a Magyar Könyuszemle (2018/1) ill. a Debreceni Szemle (2017/3) hasábjain. A szerkesztőség tervei között újabb egyetemtörténeti konferenciák anyagának tematikus közlése továbbra is szerepel. Témánkból következően profilunk természetesen interdiszciplináris jellegü, minden tudományág felső szintű oktatásának és kutatásának, valamint az egyetemi élet egyéb mozzanatainak feltárásra is igyekszünk kellő figyelmet fordítani.

Az elmúlt évtizedben tapasztalt korrekt együttműködésért a szerkesztőség ezúton is köszönetét fejezi ki a Debreceni Egyetemi Kiadó munkatársainak, valamint az egyetem vezetésének a kiadás anyagi hátterének biztosításáért. Reményeink szerint valóra válnak alapító főszerkesztőnk szavai, amelyek szerint „nem rövid időszakra alapított folyóirat a Gerundium, hanem olyan, amely sok évtized múlva is fogadja a kitűnő publikációkat”.

Ennek a célkitűzésnek igyekezett első évtizedünk megfelelni, s remélhetőleg még további évtizedekben is sikerrel járulhatunk hozzá a tudományok sokaságát magas szinten művelö, $s$ az újabb és újabb tudós nemzedékeket hívatásukra felkészítő egyetemek történetének bemutatásához, s a múltból merített tanulságoknak a jelenben történő kamatoztatásához. 